\title{
Pemberdayaan UKM yang Tergabung dalam Wanita Pengusaha Muslimah Indonesia (WPMI) Melalui Pembentukan Koperasi dan Pengembangan Website
}

\author{
Retna Sari ${ }^{1}$, Dianwicaksih Arieftiara ${ }^{2}$, Masripah ${ }^{3}$ \\ 1,2,3Universitas Pembangunan Nasional Veteran Jakarta \\ e-mail: $\underline{\text { retnasari@upnvj.ac.id }}{ }^{1}$, dianwicaksih@upnvj.ac.id ${ }^{2}$, masripah@upnvj.ac.id $^{3}$
}

\begin{abstract}
The MSME sector is proven to be the driver of the Indonesian economy, and in Indonesia the number of MSMEs owned and managed by women is quite significant and plays a big role in economic growth. Indonesian Muslim Women Entrepreneurs (WPMI) is one of the organizations that become a forum for MSMEs managed by women spread throughout Indonesia. Various problems faced by WPMI based on complaints to its members are capital difficulties when MSMEs want to develop their businesses. Limited resources so that there is a desire to synergize in concrete matters, namely as a medium of resource sharing. The need for legal entities so that MSMEs are able to compete to increase the scope of business and be able to compete to expand the reach of clients / customers, increase customer segmentation, such as large companies and government agencies. The need for display space for all products and information that are related to WPMI activities and all MSMEs are attractive and wide range based on information technology. Productivity efficiency of MSMEs in planning and calculating the price of product acquisition / cost of basic services, inventory management, financial management and accounting reporting in accordance with tax needs and fulfillment of MSME tax obligations. Solutions offered within 3 years are: the establishment of cooperatives, website development and various information systems that facilitate management, assistance in terms of financial management and taxation.
\end{abstract}

Keywords: MSME Empowerment; Establishment of Cooperatives; Website Development; MSME Information System Development; MSME Management Assistance

\begin{abstract}
Abstrak
Sektor UMKM terbukti menjadi penggerak perekonomian Indonesia, dan di Indonesia jumlah UMKM yang dimiliki dan dikelola oleh wanita terbilang sangat signifikan dan berperan besar dalam perumbuhan ekonomi. Wanita Pengusaha Muslimah Indonesia (WPMI) merupakan salah satu organisasi yang menjadi wadah UMKM yang dikelola oleh wanita yang tersebar di seluruh Indonesia. Berbagai permasalahan yang dihadapi oleh WPMI berdasarkan keluhan pada anggotanya adalah kesulitan permodalan ketika UMKM ingin mengembangkan usaha mereka. terbatasnya sumber daya sehingga timbul keinginan untuk bersinergi dalam hal yang konkrit, yaitu sebagai media berbagi sumber daya (resource sharing). Perlunya badan hukum agar UMKM mampu bersaing meningkatkan lingkup usaha dan mampu bersaing memperluas jangkauan klien/pelanggan, meningkatkan segmentasi pelanggan, misalnya perusahaan besar maupun instansi pemerintah. Perlunya ruang display bagi produk dan informasi semua yang bekenaan dengan kegiatan WPMI maupun seluruh UMKM binaan yang menarik dan luas jangkauannya berbasih teknologi informasi. Efisiensi produktifitas UMKM dalam merencanakan dan menghitung harga perolehan produk/harga pokok jasa, manajemen persediaan, pengelolaan keuangan dan pelaporan akuntansi sesuai dengan kebutuhan pajak serta pemenuhan kewajiban perpajakan UMKM. Solusi yang ditawarkan dalam kurun waktu 3 tahun adalah: pembentukan koperasi, pengembangan website dan berbagai sistem informasi yang mempermudah pengelolaan, pendampingan dalam hal pengelolaan keuangan dan perpajakan.
\end{abstract}

Kata Kunci: Pemberdayaan UMKM; Pembentukan Koperasi; Pengembangan Website; Pengembangan Sistem Informasi UMKM; Pendampingan Pengelolaan UMKM 


\section{PENDAHULUAN}

Di Indonesia, emansipasi wanita telah banyak kita lihat wujud nyata dan perannya dalam sejarah bangsa Indonesia sejak zaman perjuangan Ibu Kartini. Sampai dengan saat ini di berbagai daerah di Indonesia, wanita juga berperan sebagai penggerak perekonomian daerah maupun nasional. Hal ini didukung oleh penelitian Suharso et al. (2019) yang menyatakan bahwa wanita yang berwirausaha memiliki efek signifikan dalam pengurangan/pengetasan kemiskinan dan diakui sebagai kontributor utama ekonomi Indonesia berkelanjutan. Diberbagai daerah di Indonesia dapat kita temui pelaku usaha UMKM adalah wanita dengan beragam latar belakang dalam menjalankan usahanya, mulai dari membantu suami dalam memenuhi kebutuhan rumah tangga sampai dengan motif aktualisasi diri dan menyalurkan hobi mereka agar dapat dimanfaatkan oleh masyarakat. Menurut Brush dan Greene (2015), salah satu populasi pengusaha yang termasuk pertumbuhannya tercepat di dunia ialah pengusaha wanita.

Organisasi Wanita Pengusaha Muslimah Indonesia merupakan organisasi yang menjadi wadah \pm 500 UMKM yang dimiliki dan dikelola oleh para wanita muslimah yang tersebar di berbagai wilayah di Indonesia. Ratusan UMKM tersebut bernaung di bawah WMPI tersebar di Propinsi Jakarta, Banten, Jawa Barat, Sumatra Selatan, Nusa Tenggara Barat, dan Jawa Timur. Sebelum bergabung pada WMPI pengusaha UMKM ini mengelola bisnisnya secara individu dengan sumber daya terbatas. Salah satu tujuan WMPI adalah sebagai wadah para pengusaha wanita untuk mengembangkan usaha mereka dengan berbagai program seperti edukasi, sinergi, resources sharing dan sebagainya. Sejak didirikan pada tahun 2015 WPMI berhasil mendapatkan kerja sama dengan berbagai instansi yang bermanfaat dalam meningkatkan usaha para UMKM dibawah naungannya seperti pelatihan akuntansi, sertifikasi halal, workshop PKP-PIRT, packaging dan branding workshop digital marketing, kurasi produk. Berbagai program yang telah terlaksana tersebut dirasa masih kurang mampu untuk meningkatkan omset serta mengembangkan usaha para pengusaha wanita muslimah dibawah naungan WMPI. Sesuai dengan koordinasi awal dengan para Dewan Pengurus Pusat WPMI yang berkedudukan di Jakarta, permasalahan yang dihadapi oleh UMKM binaan adalah:

1. Permasalahan bidang sosial ekonomi dan humaniora, yaitu kesulitan permodalan, keinginan untuk bersinergi dalam hal yang konkrit sebagai media berbagi sumber daya, dan perlunya badan hukum agar UMKM mampu meningkatkan segmen dan jangkauan operasinya, efisiensi produktifitas UMKM, manajemen persediaan, pengelolaan keuangan, pelaporan akuntansi dan pemenuhan kewajiban perpajakan UMKM. Sesuai dengan hasil penelitian Azizah dan Setyawati (2018), saat ini UMKM masih menghadapi permasalahan-permasalahan seperti kurang modal, sumber daya manusia lemah, kurangnya menguasai teknologi atau pasar yang mempengaruhi kinerja usaha.

2. Permasalahan bidang teknologi informasi dan komunikasi, yaitu perlunya ruang display bagi produk dan informasi semua yang berkenaan dengan UMKM maupun WPMI, otomatisasi penghitungan harga perolehan atau harga pokok, manajemen persediaan melalui system informasi akuntansi berbasis website/aplikasi.

Dari identifikasi masalah tersebut, maka kegiatan Pengabdian Kepada Masyarakat ini adalah "Pemberdayaan UKM yang Tergabung dalam Wanita Pengusaha Muslimah Indonesia (WPMI) Melalui Pembentukan Koperasi dan Pengembangan Website".

\section{METODE PELAKSANAAN}

Berdasarkan uraian permasalahan yang telah diberikan, maka metode pelaksanaan kegiatan PKM selama meliputi:

1. Identifikasi awal dan koordinasi menyeluruh dengan seluruh stakeholder. 
2. FGD dengan mengundang narasumber dari berbagai instansi seperti kementerian koperasi, pihak notaris/ahli hukum, dsb.

3. Pendampingan bagi Dewan Pengurus Pusat (DPP) dan Dewan Pengurus Cabang (DPC) WPMI serta UMKM dibawah naungan WPMI.

4. Pelatihan yang dirancang untuk mengembangkan kualitas SDM WPMI maupun UMKM.

5. Evaluasi dan monitoring pelaksanaan PkM.

Tahapan pelaksanaan dibagi dalam 3 (tiga) tahapan yaitu

1. Tahap Persiapan, meliputi

Koordinasi dengan mitra, survei pendahuluan dan kajian atas Undang-Undang serta aturan terkait. Output tahap persiapan adalah daftar checklist atas hal-hal yang diperlukan dalam pemberdayaan UMKM dibawah WPMI.

2. Tahap Pelaksanaan, meliputi:

FGD dan seminar atas pentingnya koperasi, system informasi, manajemen persediaan dan penghitungan harga pokok, pembentukan koperasi dan pengembangan website; Pendampingan bagi Dewan Pengurus Pusat (DPP) dan Dewan Pengurus Cabang (DPC) WPMI serta UMKM dibawah naungan WPMI; kegiatan pelatihan dirancang untuk mengembangkan kualitas SDM WPMI maupun UMKM. Output tahap perlaksanaan adalah pengembangan UMKM dalam hal kreatifitas dan peningkatan jangkauan operasional.

3. Tahap Monitoring dan Evaluasi. Meliputi:

Monitoring dilakukan untuk menilai ketercapaian hasil kegiatan dan potensi penyimpangan dari perencanaan. Evaluasi dilakukan untuk menilai apakah kegiatan PKM ini telah sesuai dengan tujuan penyelenggaraannya yaitu dapat memberdayakan UMKM dibawah WMPI.

\section{HASIL dan PEMBAHASAN}

\section{Hasil Persiapan Kegiatan Pengabdian Kepada Masyarakat (PKM)}

Dunia saat ini sedang mengalami wabah virus Covid-19 yang dimulai pada awal tahun 2020 sampai dengan saat ini dan belum dapat diprediksi akan berakhir sampai kapan. Kondisi tersebut menyebabkan tidak boleh berkumpulnya orang banyak demi mencegah penyebaran virus tersebut. PKM dilaksanakan melalui daring yang dimulai dengan pertemuan, koordinasi pelaksanaan dan berdiskusi melalui zoom meeting/video conference dengan pihak WPMI.

Berikut ini disampaikan rincian pada tahap persiapan:

1. Melakukan studi pustaka mengenai pemasaran secara online dan offline produk-produk UKM yang masuk di dalam WPMI.

2. Melakukan rencana untuk pembentukan pendirian koperasi pusat WPMI. Menurut Ebue, Onyeze, dan Arinze (2015), koperasi adalah organisasi bisnis, meskipun tergolong dalam bentuk organisasi bisnis non-profit.

3. Melakukan pemetaan kebutuhan data untuk pembuatan website WPMI.

\section{Hasil Pelaksanaan Kegiatan Pengabdian Kepada Masyarakat (PKM)}

Pelaksanaan pendampingan pembentukan pendirian koperasi dan pembuatan website dilakukan melalui online (daring). WPMI merupakan mitra yang berfokus pada pemasaran produk-produk UMKM di tingkat lokal yang tersebar di beberapa kota di Indonesia. Pada kegiatan pengabdian kepada masyarakat, kami menjalin kerjasama untuk menuntaskan beberapa permasalahan yang dimiliki oleh WPMI yang menjadi hambatan 
dalam pemasaran produk-produk jualnya baik melalui online maupun offline yang akan dibantu dalam penyelesaiannya diantaranya:

- Pembuatan website

- Pemasaran via digital

- Pembuatan akun dan penjualan via IG

- Packaging produk

- Membentuk offline market

- Produk WPMI belum terdisplay dengan baik

- Ongkos kirim yang masih tinggi

- Produk UMKM dari khas masing-masing kota/daerah

Dari beberapa permasalahan yang dihadapi oleh WPMI, maka kami akan segera membantu dalam menyelesaikan permasalahan tersebut. Selain itu, WPMI juga memiliki beberapa rencana dan target yang diharapkan dapat dibantu oleh tim pengabdian kepada masyarakat dari UPNVJ. Selain pembentukan website WPMI, pemasaran via online maupun offline maka WPMI juga berencana untuk mendirikan koperasi pusat sampai koperasi lokal di masing-masing kota. UPNVJ terus melakukan persiapan dan memfasilitasi dengan membantu dalam pengumpulan syarat-syarat yang dibutuhkan dalam pendirian koperasi yang berbadan hukum. Partisipasi anggota, komitmen anggota dan kemampuan inovasi memiliki pengaruh signifikan terhadap arah pengembangan koperasi (Rusyana, Fathoni, \& Warso: 2016). Perihal yang dari awal sudah ditanamkan pada WPMI. Namun dengan adanya pandemi covid-19 maka kegiatan belum sepenuhnya dilakukan (masih dalam proses) dengan target dan jadwal yang direncanakan.

Tahap pelaksanaan dilakukan dalam 2 tahap secara tertulis. Tahap pertama pendampingan dalam rangka pembentukan pendirian koperasi dan pembuatan website dilakukan melalui online (daring). Kegiatan ini diharapkan dapat membantu dan memberikan kontribusi terhadap penyelesaian permasalah yang ada dalam WPMI. Sasaran utama yaitu ada Peningkatan kemampuan dalam pemasaran produk UKM yang masuk di WPMI. Peserta kegiatan ini adalah sebanyak 6 perwakilan pelaku usaha yang tergabung dalam WPMI yang berada dibeberapa kota. Kegiatan pendampingan juga terus berlangsung melalui whatsapp group untuk terus berkoordinasi dan memantau perkembangan sejauh mana program sudah berjalan. Waktu pelaksanaan tahap pertama dimulai pada bulan Mei sampai Juli 2020.

Tahap kedua dilakukan proses pengumpulan dokumen atau syarat-syarat yang dibutuhkan untuk melakukan pendirian koperasi pusat yang berbadan hukum. Selain itu pembentukan website juga sudah mulai berjalan dengan membuat kerangka atau menu terlebih dahulu.

\section{Proses pembuatan Website}

Konfirmasi dari ketua WPMI, sejak pendirian WPMI telah memiliki alamat domain yaitu http://dppwpmi.id/ namun karena beberapa alasan operasional maka website ini belum memiliki desain layout dan isi. Kegiatan PKM ini juga membantu pihak WPMI untuk memberikan masukan desain website yang informatif dan user friendly.

Tahap pembuatan website WPMI dimulai dari kerangka yang disajikan dibawah ini dengan menunggu kelengkapan data dari pihak WMPI. Berikut adalah tampilan awal desain website oleh tim pengembang website dari kelompok pelaksana kegiatan PKM. 


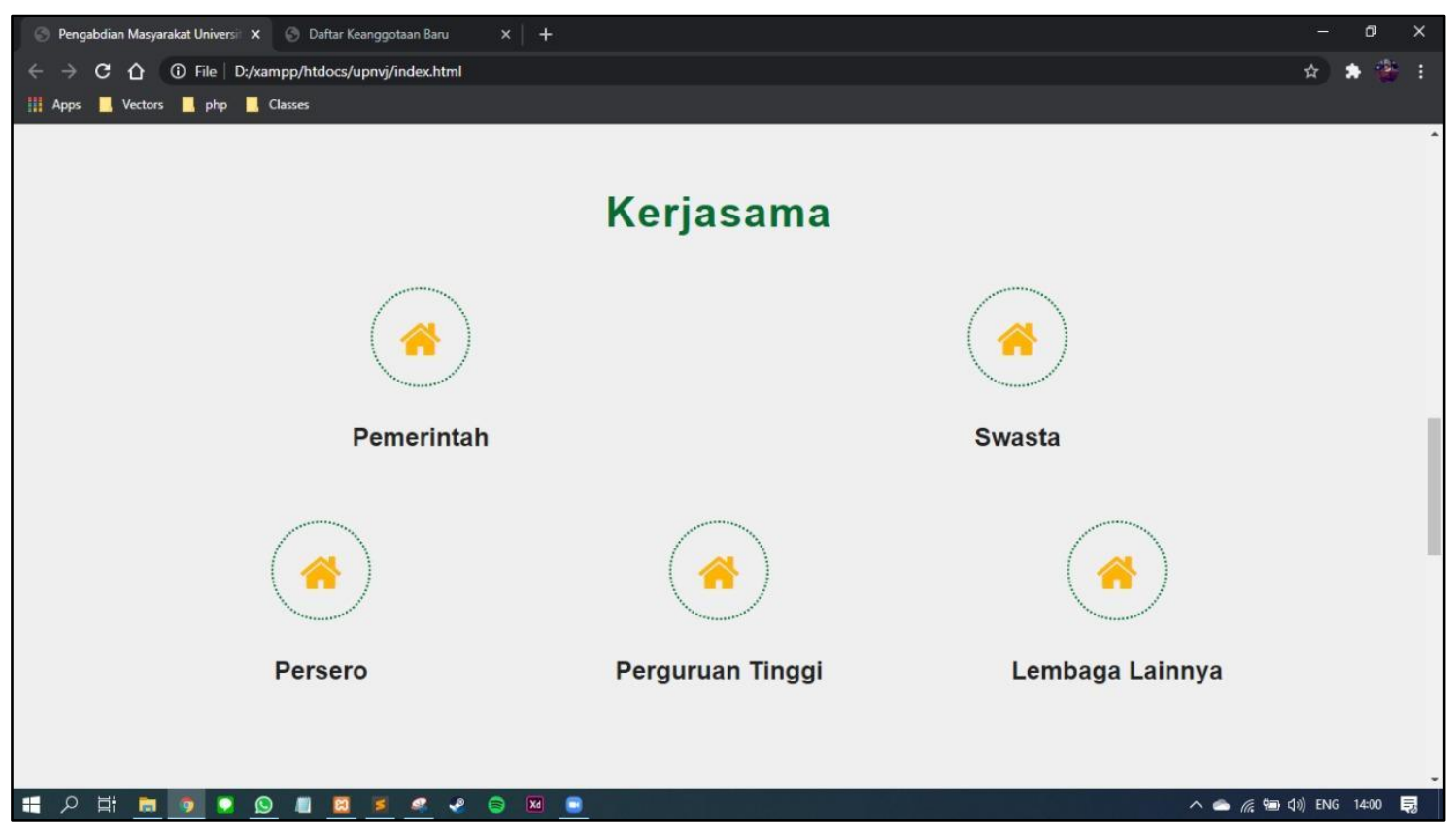

Gambar 1. Disain Awal Tampilan Menu Kerjasama Website WPMI

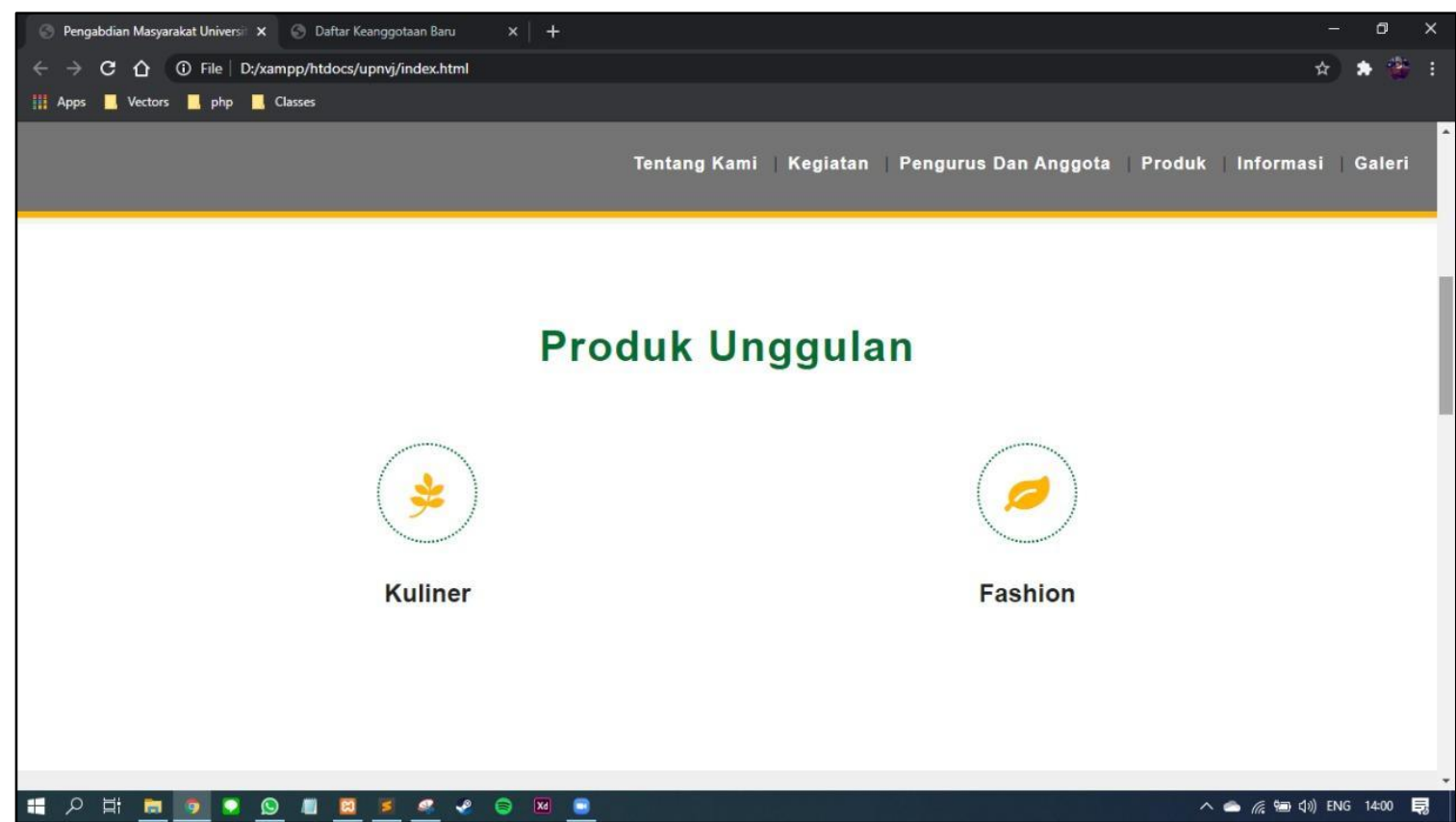

Gambar 2. Disain Awal Tampilan Menu Produk Unggulan Website WPMI

Website ini akan menampilkan semua informasi yang lengkap mengenai organisasi WPMI maupun informasi mengenai masing-masing anggota, baik produk maupun informasi lain. Berdasarkan keterangan dari pengurus WPMI, organisasi ini memiliki mimpi untuk berkembang mengingat potensi yang ada, dan tidak menutup kemungkinan akan terjaring banyak anggota baru yaitu pengusaha muslimah di seluruh Indonesia yang akan bergabung. Oleh karena itu tim pelaksana kegiatan PKM ini mengusulkan kepada pengurus 
WPMI untuk menjadikan website ini sebagai one-stop service and information, dengan demikian calon anggota baru WPMI dapat mendapatkan info lengkap dari web kemudian langsung mendaftar menjadi anggota dengan mengisi formulir pendaftaran yang tersemat didalam menu website seperti gambar berikut.

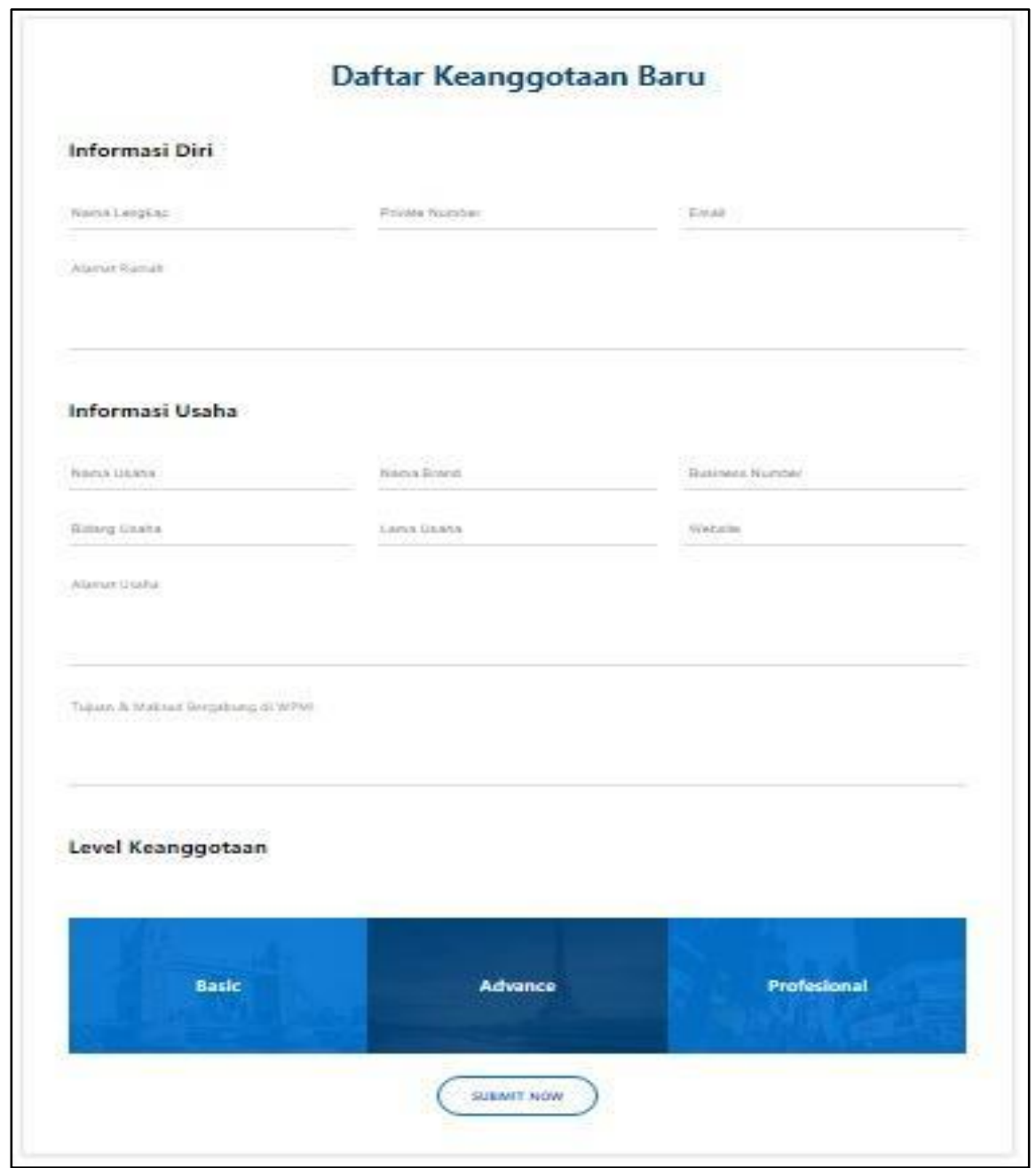

Gambar 3. Disain Awal Tampilan Pendaftaran Anggota Baru di Website WPMI

Seiring dengan visi dan misi WPMI, organisasi ini berencana akan mengembangkan lingkup dan jangkauan kegiatannya tidak hanya di dalam negeri namun juga global. Untuk itu disain website disesuaikan pula untuk mengakomodir kebutuhan ini dengan menambahkan menu sebagai berikut: 


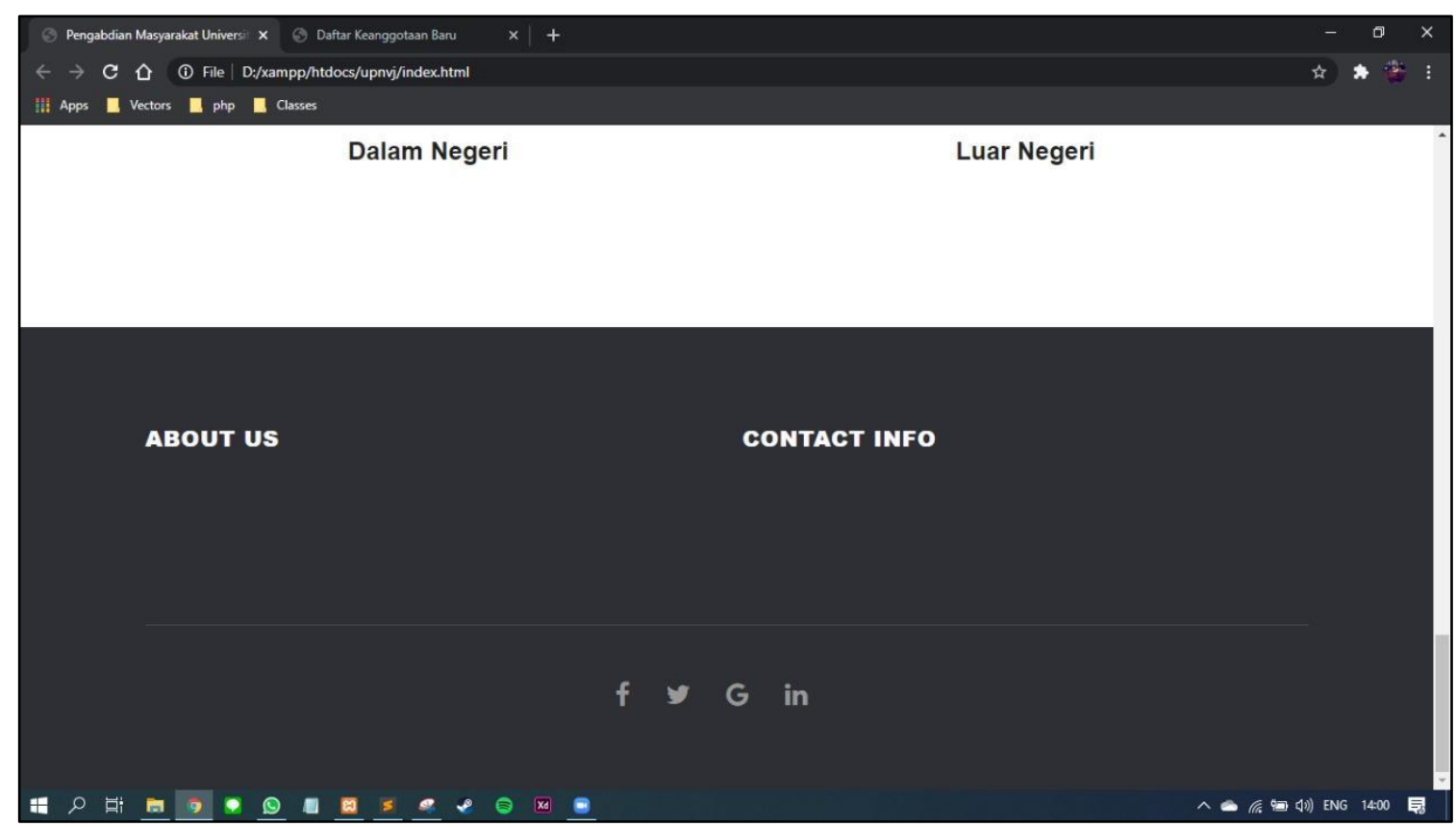

Gambar 4. Desain Awal Tampilan Menu Lingkup Kegiatan/Peristiwa di Website WPMI

Sampai dengan saat ini mengingat jumlah anggota WPMI yang berjumlah ratusan, maka proses pengembangan website sedang berlangsung. Adapun kendala yang dihadapi dalam pengembangan website ini adalah terkumpulnya database untuk di masukkan kedalam website serta kesibukan dari para pengelola WPMI yang juga semuanya pengusaha dalam koordinasi pengembangan web.

\section{UCAPAN TERIMA KASIH}

Kami mengucapkan terimakasih kepada UPN Veteran Jakarta yang telah memfasilitasi dalam pelaksanaan kegiatan Pengabdian Kepada Masyarakat baik dari sisi pendanaan maupun fasilitas lainnya. Ucapan terima kasih juga kami sampaikan kepada Mitra kami yaitu Wanita Pengusaha Muslimah Indonesia (WPMI) atas kerjasamanya dalam melakukan penyuluhan pembentukan koperasi dan pembuatan website yang diharapkan dapat membantu dalam pengembangan kegiatan usaha WPMI yang berkelanjutan.

\section{KESIMPULAN}

Kegiatan Pengabdian Kepada Masyarakat ini dilakukan bertujuan untuk mendampingi Pendirian Koperasi dan pembentukan website WMPI yang dikelola oleh beberapa pengelola unit bisnis yang sudah tergabung dalam WPMI tersebut. Pelaksanaan PkM ini diikuti oleh 6 perwakilan pengelola UKM yang sudah tergabung dalam WPMI yang berada dalam beberapa kota.

Hasil pelaksanaan PkM ini berjalan dengan lancar, dilihat dengan peningkatan pengetahuan dan kemampuan peserta pengelola unit bisnis dalam memahami transaksi bisnis dan pemasaran melalui online dan offline. Respon dari WPMI sangat positif dalam program kegiatan PkM ini karena dirasakan sangat membantu dalam pemasaran produk dengan pembentukan pendirian koperasi maupun pembentukan website WPMI. Peserta mengikuti seluruh tahapan kegiatan dengan semangat dan antusiasme yang tinggi, serta dari umpan balik peserta, hampir seluruh peserta menghendaki diadakan kegiatan pendampingan di bidang lain yang bermanfaat bagi usaha mereka secara berkelanjutan. 


\section{DAFTAR PUSTAKA}

Azizah, S.N., \& Setyawati, H.A. (2018). Wanita dan Peranannya dalam Memajukan UMKM Batik di Kebumen. Prosiding Seminar Nasional LPPM, November, Purwokerto.

Brush, C.G., \& Greene, P.G. (2015). Women's Entrepreneurship. Wiley Encyclopedia of Management.

Ebue, M.I., Onyeze, C.N., \& Arinze, A. (2015). Poor Management and Accounting System as One of the Problems of Co-Operative Societies: A Survey of Some Selected Cooperative Societies in Enugu North Local Government Area.

Perda No. 7 Tahun 2017 Tentang Rencana Pembangunan Jangka Menengah Daerah Provinsi Banten Tahun 2017-2022.

Halim, W. 2017. Rancangan RPJMD Provinsi Banten 2017 - 2022. Tersedia pada https://ppid.bantenprov.go.id/read/berita/5960/Gubernur-Banten-WahidinHalim-Program-OPD-dalam-RPJMD-Harus-Selaras-Dengan-Visi-Misi-Pemprov Banten.html. Diakses pada 7 September 2019 pk. 22.19 WIB.

Haris, A. 2018. UMKM di Provinsi Banten Alami Peningkatan. Tersedia di http://bisnisbanten.com/umkm-di-provinsi-banten-alami-peningkatan-inifaktanya. Diakses pada 7 September pk. 22.24 WIB.

Rusyana, Fathoni, A., \& Warso, M.M. (2016). Pengaruh Partisipasi, Komitmen dan Kemampuan Inovasi Anggota terhadap Arah Pengembangan Koperasi (Studi Empiris pada Koperasi Primer S-22 Kodam IV Diponegoro Kota Semarang). Journal of Management, Vol. 2, No.2.

Suharso, P., Ani, H.M., Sukidin, Sedyati, R.N., Hartanto, W., \& Mardiyana, L.O. (2019). Women Enterpreneurs in Jember: Effect of Social Capital and Virtual Geography. Paper dipresentasikan di The First International Conference on Environmental Geography and Geography Education (ICEGE), University of Jember, East Java, Indonesia.

Anonymous. Pengertian koperasi serba usaha Tersedia di https://kementeriankoperasi.com/pengertian-koperasi-serba-usaha. Diakses pada 7 September 2019. Pk.22.29 WIB 